\title{
Acute respiratory infections and their complications
}

\author{
Yu. M. Andreichyn, V. O. Kachor, Ya. I. Yosyk, N. A. Nychyk, I. I. Hanberher
}

I. Horbachevsky Ternopil State Medical University, Ukraine

Key words:

influenza,

respiratory

infections.

Zaporozhye

medical journal

2018; 20 (6), 848-852

DOl:

$10.14739 / 2310-1210$

2018.6.146777

E-mail:

yandrachyn@

tdmu.edu.ua

Кнючові слова: грип, гострі респіраторні інфекції.

Запорізький медичний

журнак. - 2018. -

T. 20, № 6(111). -

C. 848-852
The aim of the study is to summarize data on the epidemiological features, clinical manifestations and peculiarities of complications of influenza and other acute respiratory infections.

Materials and methods. The modern scientific literature about influenza and other ARVI was analysed.

Conclusions. At present the flu and other acute respiratory infections are the most common diseases that cause frequent epidemics and even pandemics and are an urgent matter worldwide. Influenza is dangerous for the elderly and infants in particular. The most recent data on the disease, peculiarities of its spreading, nature of epidemics in 2009 and 2016, characteristic clinical symptoms, main complications (pneumonia, acute respiratory distress syndrome, sinusitis) and their clinical aspects are presented. Influenza caused by a new California influenza A (H1N1) virus, which may cause pandemic outbreaks and is a typical emergent infection, is another topical issue. It should be noted that the new influenza A (H1N1) virus is rapidly spreading around the planet and can exchange genetic information with seasonal and avian influenza viruses. The mutation that originates in this case can significantly increase its pathogenic properties and make the mutant strain more aggressive.

\section{Гострі респіраторні інфекції та їх ускиаднення}

\section{Ю. М. Андрейчин, В. О. Качор, Я. І. Йосик, Н. А. Ничик, І. І. Ганьбергер}

Мета роботи - формування сучасних поглядів про епідеміологічні особливості, етіологічну структуру, клінічні прояви та основні ускладнення грипу та інших гострих респіраторних інфекцій на основі аналізу сучасної наукової літератури.

Матеріали та методи. Аналіз та узагальнення даних сучасної наукової літератури про грип і ГРВІ.

Висновки. Нині грип та інші гострі респіраторні інфекції залишаються найбільш масовими захворюваннями. Грип спричиняє часті епідемії та навіть пандемії, є проблемою світового значення. Він особливо небезпечний для людей похилого віку, вагітних і немовлят. Наведені найновіші дані про цю хворобу та їі поширення, особливості епідемій 2009 p. і 2016 р., типові клінічні прояви, основні ускладнення (пневмонія, респіраторний дистрес-синдром, синусити) та їхню клінічну картину. Висвітлено чергову проблему грипу, що спричинений новим вірусом грипу A (H1N1) Каліфорнія - типової емерджентної інфекції, котра може набути розмахів пандемії. Новий вірус грипу А (H1N1), стрімко поширюючись, може обмінятися генетичною інформацією з вірусами сезонного та пташиного грипу. Мутація, що виникне, може суттєво підвищити його патогенні властивості, зробити мутантний штам набагато агресивнішим.
Ключевые слова:

грипп, острые респираторные инфекции.

Запорожский медицинский

журнал. - 2018. -

T. 20, № 6(111). -

C. 848-852

\section{Острые респираторные инфекции и их осложнения}

\section{Ю. М. Анарейчин, В. А. Качор, Я. И. Йосик, Н. А. Нычик, И. И. Ганьбергер}

Цель работы - формирование современных представлений об эпидемиологических особенностях, этиологической структуре, клинических проявлениях и основных осложнениях гриппа и других острых респираторных инфекций на основе анализа современной научной литературы.

Материалы и методы. Анализ и обобщение данных современной научной литературы о гриппе и ОРВИ.

Выводы. На сегодня грипп и острые респираторные инфекции остаются проблемой мирового значения, вызывая наиболее массовые заболевания, частые эпидемии и даже пандемии. Особо опасен грипп для пожилых, беременных и младенцев. Приведены новейшие данные об этой болезни, ее распространении, особенностях эпидемий 2009 г. и 2016 г., типичных клинических проявлениях, основных осложнениях (пневмония, респираторный дистресс-синдром, синусит) и их клинической картине. Освещена очередная проблема гриппа, вызванного новым вирусом гриппа А (H1N1) Калифорния - типичной эмерджентной инфекции, которая может приобрести размах пандемии. В результате стремительного распространения нового вируса гриппа A (H1N1), возможен обмен его генетической информации с вирусами сезонного и птичьего гриппа. Мутация, которая возникнет при этом, приведет к повышению патогенных свойств, что сделает мутантный штамм более агрессивным.

Recently, acute respiratory viral infection (ARVI) has been dominating in the structure of infectious pathology of many countries regardless of the degree of their economic development [1]. They make up about $90.0 \%$ of all cases and the incidence of infectious diseases annually is from 3 to 5 million serious flu cases [2,3]. ARVI is an etiologically heterogeneous group of infectious diseases of respiratory tract, which have similar mechanisms of development, epidemiological and clinical characteristics. Influenza and other ARVI is an urgent matter because of their frequency and prevalence as well as due to causing a social and economic harm.

In recent years, a significant influence of mixed infections on the development of ARVI that are accompanied by a more severe course and development of various complications has been noted [4-7]. 


\section{The aim}

The aim of the study is to summarize data on epidemiological features, clinical manifestations and peculiarities of complications of influenza and other acute respiratory infections.

\section{Materials and methods}

The scientific literature within last 10 years was analyzed. Publications from previous years were taken into account in the absence of new research in this area or authors are recognized by experts on the subject and conclusions have not lost relevance. During searching we used scientometric and bibliographic databases as Google Scholar, PubMed, Scopus, ScienceDirect.

In $23 \%$ of the patients more than two respiratory viruses were revealed $[8,9]$. However, in $20-30 \%$ of cases the pathogen was not identifiable. It is established that Chlamydia and pneumonia bacteria may also be the pathogens of ARVI [10]. One of the main features of influenza virus is its ability to cause frequent epidemics and pandemics, so it may be affirmed that it is a global topical issue [11].

In the period of an epidemic the disease involves from $5 \%$ to $20 \%$ of the population. During an influenza pandemic, when significant changes of the virus properties take place, every second person may be taken ill worldwide $[12,13]$

New strains of influenza, which were first registered in China, Southeast Asia or America, quickly spread across the earth. In Ukraine up to 10-15 million patients with respiratory infections are registered annually $[14,15]$.

Influenza and other ARVI affect human health. These maladies can worsen the course of co-morbidities that is dangerous for people with chronic pathologies (respiratory and cardiovascular system, pancreatic cancer, central nervous system, etc.). The flu is especially dangerous for the elderly people, pregnant women and infants [16-18].

Among the major pathogens affecting respiratory tract (there are more than 200 of them) there are: parainfluenza and rhinovirus infections, which cause up to $30-50 \%$ of ARVI cases of all age groups, coronavirus - up to $15 \%$; enterovirus and adenovirus - $5 \%$. According to the $\mathrm{WHO}$, as of June 2015, 126 cases of coronavirus infection were registered in the Republic of South Korea, 62 were laboratory confirmed, 6 of them were fatal, together with 10 (7.9\%) among health care workers [19].

The highest annual rate of mortality of influenza and ARVI in the world is more than 4.5 million people (the mortality rate of tuberculosis is 3.1 million, malaria -2.2 million, hepatitis - 1.1 million) [20,21].

In Ukraine during the epidemic seasons 2009-2010 more than 6355402 people contracted an influenza and other ARVI and 1127 died. 466 cases of influenzaA/H1N1sw were confirmed, $16.5 \%$ of them were fatal as a result of complications development, mainly of pneumonia. The features of clinical course of pneumonia were: a severe disease onset with severe intoxication syndrome and rapid development of respiratory distress syndrome [23-25].

During the epidemic of 2015-2016 the virus $\mathrm{A} / \mathrm{H} 1 \mathrm{~N} 1 \mathrm{sw}$ was dominant in Europe again, in Ukraine as well, and caused its severe clinical course. Comparing the peculiarities of epidemic process of this epidemic season with the previous ones, the late morbidity increase should be emphasized. As of February 22, 2016 in Ukraine more than 4 million cases of influenza and other ARVI, as well as 336 mortality cases (including 5 children and 2 pregnant) were registered [26].

The flu and ARVI are often complicated by bacterial infection and formation of viral and bacterial associations, which lead to more severe course and tchanges in clinical picture of the disease. The most frequent complications are: acute bronchitis, laryngotracheobronchitis, bronchiolitis, pneumonia, lung abscesses, empyema and pneumothorax. The exacerbations of chronic bronchitis and/or chronic obstructive lung disease, bronchial asthma and cystic fibrosis are frequent.

Pneumonia develops in patients with influenza type A, as well as $B$. There are primary viral pneumonia (caused by a direct viral lung lesion) and secondary bacterial pneumonia (it can be combined with the initial viral or be an independent late complication of influenza). It should be noted that in people of young age in $60 \%$ of cases early pneumonia is prevalent, it occurs in the first few days of the disease, usually associated with catarrhal syndrome and total intoxication that cause difficulties for timely diagnosis of these complications.

It is established that the most deaths from the flu are not caused by the disease directly, but by the complications that are registered during pandemics as well as during periods of seasonal virus activity in between pandemics. In the clinical diversity of complications pneumonia takes the first place (80-90\%), the frequency of its revealing is up to $10 \%$ among all the sick patients and up to $50 \%$ among the hospitalized ones $[27,28]$.

Depending on the etiologic factor in cases of influenza pneumonia is defined as: primary (viral), secondary (viralbacteria) and tertiary (bacterial). Primary pneumonia is a direct lung involvement into the pathological process caused by an influenza virus, more frequently of pandemic strains. It develops on the $2^{\text {nd }}-3^{\text {rd }}$ day after the disease onset, usually has a severe course, as evidenced by the signs of acute respiratory failure [29-31].

According to the research and clinical observations, which were carried out in Ukraine and abroad, the last pandemic of 2009-2010 years caused by the influenza virus $\mathrm{A} / \mathrm{H} 1 \mathrm{~N} 1$, unlike the epidemics and pandemics of 14 previous decades, involved development of severe course of viral pneumonia complicated with acute respiratory distress syndrome (ARDS) that resulted in necessary treatment of patients in resuscitation and intensive care units and caused most of the deaths. According to the literature, the number of patients in need of intensive care in different countries was $10.0-25.0 \%$ of all hospitalized with influenza and mortality rate from pneumonia complicated with $A R V I$ and multiple organ insufficiency (MOI) was 17-54 \% [32-35].

According to official statistics in Ukraine from October 29, 2009 till March 18, 2010 the total number of patients with the flu and ARVI was 6.3 million and the number of deaths reached 1127363900 of the sick required hospitalization, together with 126026 (34.6\% of the amount of the hospitalized) patients with pneumonia [36].

In other countries, the frequency of flu-associated pneumonia among the hospitalized was slightly higher and amounted to $40 \%$ in the United States and $49.0 \%$ 
in Australia [37]. In cases of secondary pneumonia, viralbacterial one, the interval between the first respiratory symptoms and the signs of lung involvement is more than 4-7 days. The notion of 'viral-bacterial' is quite uncertain and means the increase of bacterial component influence in terms of pneumonia development since the first catarrhal flu symptoms. As a result, viral and bacterial pneumonia involve a combination of signs of primary and secondary pneumonia [38]. This causation occurs as a result of inhibition of nonspecific and specific antiviral protection factors by a virus that leads to the activation of endogenous microflora of upper respiratory tract. Mostly, gram-positive bacteria are the bacterial pathogens of mixed pneumonia. Streptococcus pneumonia (48\%) and Staphylococcus aureus (19\%) dominate among them, and are found in sputum simultaneously with influenza viruses [39-41].

Tertiary bacterial pneumonia develops in 10-14 days after the disease onset in patients with chronic diseases of respiratory tract. It is established that this lung lesion is caused by the activated aggressive gram-negative bacterial automicroflora [42]. World literature presents a number of studies of the bacterial superinfection influence in cases of the flu. For instance, according to the research of lung tissue of the dead during the flu pandemic of 1918-1919, it was proved that in most (96\%) cases the histological signs of severe bacterial pneumonia caused by Streptococcus pneumoniae took place [42-43].

At present it is proved that severe and complicated course of influenza develops mainly in patients of risk groups: pregnant women, patients suffering from diabetes, obesity, chronic lung and heart diseases, as well as the elderly [44-46].

It should be noted that pandemics of the last century involved complications development in patients older than 60 years [47]. The characteristic features of the last flu $\mathrm{A} / \mathrm{H} 1 \mathrm{~N} 1$ pandemic was the shift of risk factor toward young and middle aged persons. So, the analysis of 642 cases of severe and complicated course of influenza that was held in the United States, proved that $60 \%$ of the patients were persons younger than 18 years old and only $5 \%$ were people older than 50 years old [48]. Some scientists explain the low percentage of the elderly people by immunologic memory in this category of patients that is proved by the presence of protective titles of cross reacting antibodies to the pandemic influenza $\mathrm{A} / \mathrm{H} 1 \mathrm{~N} 1$ in blood serum in $33 \%$ of the examined of over 60 years old in age vs. 6-9\% of the 18-60-year-old persons and their total absence in children. Thus, the research carried out by the Centers for Disease and Prevention proved that persons, who were born before 1930, were more protected during the pandemic of 2009-2010 compared with those born after 1980 [49]. The proof of this is the results of the study of age structure of the deceased from influenza complicated with pneumonia in 2009 in Mexico, which first faced the virus $\mathrm{A} / \mathrm{H} 1 \mathrm{~N} 1 /$ California/04/2009. $87 \%$ of the dead were aged from 5 to 59 years old compared with $17 \%$ of this age group patients during the past epidemics [50].

Acute sinusitis usually develops as a complication of influenza and other ARVI associated with low tissue and systemic immunity [51]. The etiology of sinusitis comprises sinus infection with diverse flora (bacteria, fungi, viruses), which is often present in nasal passages. Except influenza virus there are rhino-, adeno-, reo-, parainfluenza virus, respiratory syncytial virus, corona virus, Coxsackie virus and Echovirus [52]. Viral infection causes significant structural failure of respiratory epithelium, up to its destruction. It promotes invasion of bacteria in the deep layers of mucosa and formation of bacterial foci [53].

The viruses cause ciliated epithelium dysfunction (transport, secretory, protective). Thus, the slowing down of natural mucus secretion takes place and the duration of bacteria contact with epithelium increases and their colonization of mucosa intensifies. In course of time the metaplasia of epithelium into transitional and multilayer squamous one as well as thickening of basal membrane take place that makes the secretion of excretions out of submucosal glands difficult and leads to their atrophy. Eventually the synthesis of this excretion is decreased and mucoid serous layer becomes thinner that cause frequent exacerbation of inflammation [54]. 73 patients with maxillary sinusitis underwent viral examinations, 46 of them suffered from acute and 27 - from chronic form of the disease. The age of the patients ranged from 18 to 68 years. There were 41 male and 32 female patients. The presence of HBsAg and anti-HCV in blood of patients was investigated by elisa test, as well as the $\operatorname{lgM}$ and $\lg G$ antibodies to herpes febrilis type $1 / 2$ and cytomegalovirus. The positive results were evidenced in $48(65.8 \%)$ patients [55]. The influence of viruses in the patients with chronic rhinosinusitis has not been fully investigated, partly due to diagnostic difficulties in virus distinguishing. The frequency of viral revealing was $41 \%$. Rhinovirus was detected in $24 \%$ of the examined, metapneumovirus - in $16 \%$ [56]. According to other studies, corona virus is the most common virus that can be crucial in exacerbation of chronic rhinosinusitis symptoms $[57,58]$.

\section{Conclusions}

Thus, it is established that at present influenza and other ARVI are the most mass diseases, which cause frequent epidemics and pandemics and are an urgent matter worldwide. The flu affects human health much; it also decreases body defenses and may cause various diseases of upper and lower respiratory tract, central nervous system, kidneys and other organs. Moreover, the flu can exacerbate the course of co-morbidities that is dangerous for people with chronic diseases (respiratory and cardiovascular system, pancreatic cancer, central nervous system, etc.). Influenza is very dangerous for the elderly, pregnant and infants in particular.

Prospects for further research. Knowledge about complications of influenza and other acute respiratory viral infections will allow practitioners to use up-to-date diagnostic and treatment methods in a timely manner for their prevention or rapid elimination of causative agents.

Conflicts of interest: authors have no conflict of interest to declare. Конфлікт інтересів: віАсутній.

Information about authors:

Andreichyn Yu. M., MD, PhD, DSc, Associate Professor of the Department of Otorhinolaryngology, Ophthalmology and Neurosurgery, I. Horbachevsky Ternopil State Medical University, Ukraine. 
Kachor V. O., MD, PhD, Associate Professor of the Department of Infectious Diseases and Epidemiology, I. Horbachevsky Ternopil State Medical University, Ukraine.

Yosyk Ya. I., MD, PhD, Assistant of the Department of Infectious Diseases and Epidemiology of I. Horbachevsky Ternopil State Medical University, Ukraine.

Nychyk N. A., MD, PhD, Associate Professor of the Department of Infectious Diseases and Epidemiology, I. Horbachevsky Ternopil State Medical University, Ukraine.

Hanberher I. I., MD, PhD, Assistant of the Department of Propedeutics to Internal Medicine and Phthisiology, I. Horbachevsky Ternopil State Medical University, Ukraine.

\section{Відомості про авторів:}

АнАрейчин Ю. М.. А-р меА. наук, Аоцент Каф. отоларингології, офтальмології та нейрохірургії, АВНЗ Тернопільський державний медичний університет імені І. Я. Горбачевського, Україна. Качор В. О., канА. меА. наук, Аоцент каф. інфекційних хвороб з епіАеміологією, шкірними і венеричними хворобами, АВНЗ Тернопільський Аержавний медичний університет імені І. Я. Горбачевського, Україна.

Йосик Я. І., канА. меА. наук, асистент каф. інфекційних хвороб з епідеміологією, шкірними і венеричними хворобами, АВНЗ Тернопільський Аержавний медичний університет імені І. Я. Горбачевського, Україна.

Ничик Н. А., канА. меА. наук, Аоцент каф. інфекційних хвороб з епідеміологією, шкірними і венеричними хворобами, АВНЗ Тернопільський Аержавний медичний університет імені І. Я. Горбачевського, Україна.

Ганьбергер І. І., канд. меА. наук, асистент каф. пропеАевтики внутрішньої меАицини та фтизіатрії АВНЗ Тернопільський Аержавний медичний університет імені І. Я. Горбачевського, Україна.

\section{Сведения об авторах:}

Андрейчин Ю. М., А-р меА. наук, Аоцент каф. отоларингологии, офтальмологии и нейрохирургии, ГВУЗ Тернопольский государственный медицинский университет

имени И. Я. Горбачевского, Украина.

Качор В. А., канА. меА. наук, Аоцент каф. инфекционных болезней с эпиАемиологией, кожными и венерическими болезнями, ГВУЗ Тернопольский госуАарственный меАицинский университет имени И. Я. Горбачевского, Украина.

Йосик Я. И., канА. меА. наук, ассистент каф. инфекционных болезней с эпиАемиологией, кожными и венерическими болезнями, ГВУЗ Тернопольский государственный медицинский университет имени И. Я. Горбачевского, Украина.

Нычик Н. А., канА. меА. наук, доцент каф. инфекционных болезней с эпиАемиологией, кожными и венерическими болезнями, ГВУЗ Тернопольский госуАарственный медицинский университет имени И. Я. Горбачевского, Украина. Ганьбергер И. И., канА. меА. наук, ассистент каф. пропедевтики внутренней медицины и фтизиатрии, ГВУЗ Тернопольский государственный медицинский университет имени И. Я. Горбачевского, Украина.

Надійшла Ао реАакції / Received: 09.02.2018

Після Аоопрацювання / Revised: 21.02.2018

Прийнято Ао Аруку / Accepted: 01.03.2018

\section{References}

[1] WHO Influenza update, 2018. http://www.who.int/influenza/surveillance monitoring/updates/latest_update_GIP_surveillance/en/.

[2] Buchholz, U., Remschmidt, C., Heiden, an der M., Tolksdorf, K., et al. (2013). Acute respiratory infections and influenza-like illnesses: how many does a person have in a year? Options for the Control of Influenza VIII. (P. 251). Cape Town.

[3] Wouters, E. F. M. (2002). Chronic obstructive pulmonary disease: systemic effects of COPD. Thorax, 57(12), 1067-1070.

[4] Chertow, D. S., \& Memoli, M. J. (2013). Bacterial coinfection in Influenza A. JAMA, 309(3), 275-82. doi: 10.1001/jama.2012.194139.

[5] (2010). Centers for Disease Control and Prevention (CDC) Patients hospitalized with 2009 pandemic influenza A (H1N1) - New York City, May 2009 MMWR Morb. Mortal. Wkly Rep, 58(51), 1436-1440.
[6] Ghedin, E., Fitch, A., Boyne, A., Griesemer, S., DePasse, J., Bera, J., et al. (2009). Mixed infection and the genesis of influenza virus diversity. J. Virol., 83(17), 8832-41. doi: 10.1128/JVI.00773-09.

[7] Hoffmann, J., Perret, M., Ferraris, O., \& Telles, J-N. (2013). The role of antigen presenting cells induced by influenza and pneumococcal coinfections: an in vitro model. Options for the Control of Influenza VIII, (P. 295). Cape Town

[8] Martin-Loeches, I., Sanchez-Corral, A., Diaz, E., Granada, R. M., Zaragoza, R., \& Villavicencio, C. (2011). Community-acquired respiratory co-infection (CARC) in critically ill patients infected with pandemic 2009 influenza A (H1N1) virus infection. Chest, 139(3), 555-562. doi: 10.1378/chest.10-1396.

[9] Abdullah Brooks, W. (2013). Paramyxovirus impact (RSV, HMPV, PIV) in children; New Studies of RVIs. Influenza and Other Respiratory Virus Infections: Advances in Clinical Management. Proceedings of the Third ISIRV-Antiviral Group Conference. Tokyo.

[10] Chertow, D. S., \& Memoli, M. J. (2013). Bacterial coinfection in Influenza A. JAMA, 309(3), 275-282. doi: 10.1001/jama.2012.194139.

[11] Besselaar, T. G., Lièvre, M., Drager Dayal, R., \& Naidoo, D. (2013). WHO efforts on global capacity of influenza virus detection and antiviral susceptibility monitoring. Options for the Control of Influenza VIII, (P. 540). Cape Town.

[12] WHO Global influenza Surveillance Network, 2009. Retrieved from http://www.who.int/csr/disease/influenza/surveillance/en/.

[13] Kamps, B. S., Hoffmann, C., \& Preiser, W. (Eds.). (2006). Influenza Report. Paris: Flying Publisher, Cagliari, Wuppertal, Sevilla

[14] Martin-Loeches, I., Sanchez-Corral, A., Diaz, E., Granada, R. M., Zaragoza, R., Villavicencio, C., et al. (2011). Community-acquired respiratory co-infection (CARC) in critically ill patients infected with pandemic 2009 influenza A (H1N1) virus infection. Chest, 139(3), 555-562. doi: 10.1378/chest.10-1396.

[15] Mironenko, A., Onyshchenko, O., \& Holubka, O. (2013) Influenza sentinel surveillance in Ukraine and characteristics of isolates during the season 2012-2013. Options for the Control of Influenza VIII, (P. 636). Cape Town.

[16] Zhou1, Y., Wu1, P., \& Lau1 E. (2013). Influenza and risk of mortality among people with chronic medical conditions. Options for the Control of Influenza VIII, (P. 665-666). Cape Town.

[17] Short, K. R., Diavatopoulos, D. A., Thornton, R., Pedersen, J., Strugnell, R. A., Wise, A. K., et al. (2011). Influenza virus induces bacterial and nonbacterial otitis media.. The J. of Infect. Dis, 204(12), 1857-1865. doi: 10.1093/infdis/jir618.

[18] Shigeru Saito (2014). Influenza and Other RVIs in Pregnancy. Influenza and Other Respiratory Virus Infections: Advances in Clinical Management. Proceedings of the Third ISIRV-Antiviral Group Conference. Tokyo.

[19] Novel coronavirus. ISIRV report. Retrieved from http://www.isirv.org/ site/index.php/news/2-uncategorised/197-novel-coronavirus.

[20] Mazick, A. (2013). Mortality Monitoring for public health action in Europe, EuroMOMO: an important tool for influenza surveillance and impact assessment, on behalf of the Network EuroMOMO. Options for the Control of Influenza VIII, (P. 237). Cape Town.

[21] Huang, C. L., Nguyen, P. A., Kuo, P. L., Iqbal, U., Hsu, Y. H., Jian, W. S. (2013). Influenza vaccination and reduction of risk in ischemic heart disease among chronic obstructive pulmonary elderly. Computer Methods and Programs in Biomedicine, 111(507), 511.

[22] Thomson, A. (2005). The Cytokine Handbook. London: Acad. Press.

[23] Bauer, T. T., Montón, C., Torres, A., Cabello, H., Fillela, X., Maldonado, A., et al. (2000). Comparison of systemic cytokine levels in patients with acute respiratory distress syndrome, severe pneumonia, and controls. Thorax, 55(1), 46-52. doi: [10.1136/thorax.55.1.46].

[24] Chollet-Martin, S., Rousset, F., \& Chastre, J. (1996). Cytokines in adult respiratory distress syndrome. Lancet, 344, 1440.

[25] Strum, J. A. (2015). Adult respiratory Distress Syndrome. Berlin, Hiedelberg.

[26] Nekrasov, L. S., Escort, V. M., Dihanovska, T. A. (2016). Flu and ADVI in Ukraine: Newsletter.

[27] Gorbea, C., Makar, K. A., Pauschinger, M., Pratt, G., Bersola, J. L., Varela, J., et al. (2010). Role for Toll-like Receptor 3 Variants in Host Susceptibility to Enteroviral Myocarditis and Dilated Cardiomyopathy. Journal of Biological Chemistry, 285(30), 23208-23. doi: 10.1074/ jbc.M109.047464.

[28] Rothberg, M. B., Haessler, S. D., \& Brown, R. B. (2008). Complications of Viral Influenza. The American Journal of Medicine, 121(4), 258-64. doi: 10.1016/j.amjmed.2007.10.040.

[29] Almond, M. H., McAuley, D. F., Wise, M. P., \& Griffiths, M. J. (2012). Influenza-related pneumonia. Clin. Med., 12(1), 67-70. doi: 10.7861/ clinmedicine.12-1-67.

[30] Rello, J., \& Pop-Vicas, A. (2009). Clinical review: Primary influenza viral pneumonia. Critical Care, 13(6), 235. doi: 10.1186/cc8183.

[31] Ruuskanen, O., Lahti, E., \& Jennings, L. C. (2011). Viral pneumonia Lancet, 377, 1264-1275. 
[32] Perez-Padilla, R., de la Rosa-Zamboni, D., Ponce de Leon, S., Hernandez, M., Quiñones-Falconi, F., \& Bautista, E. (2009). Pneumonia and respiratory failure from swine-origin influenza $\mathrm{A}(\mathrm{H} 1 \mathrm{~N} 1)$ in Mexico. $N$. Engl. J. Med., 361(7), 680-9. doi: 10.1056/NEJMoa0904252.

[33] Centers for Disease Control and Prevention (CDC). (2009). Hospitalized patients with novel influenza A (H1N1) virus infection - California, April - May, 2009. MMWR Morb Mortal Wkly Rep., 58(19), 536-41.

[34] Dawood, F. S., Jain, S., Finelli, L., Shaw, M. W., Lindstrom, S., Garten, R. J., et al. (2009). Emergence of a novel swine-origin influenza A (H1N1) virus in humans. N. Engl. J. Med., 360(25), 2605-15. doi: 10.1056/NEJMoa0903810.

[35] Domínguez-Cherit, G., Lapinsky, S. E., Macias, A. E., Pinto, R. Espinosa-Perez, L., de la Torre, A., et al. (2009). Critically ill patients with influenza A (H1N1 novel) in Mexico. JAMA, 302(17), 1880-7. doi: 10.1001/jama.2009.1536.

[36] (2010) The Ministry of health of Ukraine/information on the incidence of influenza and acute respiratory diseases and their complications (pneumonia, etc.) for the period from 22 to 28 March (12-week) 2010 Retrieved from http://www.moz.gov.ua/ua/main/press/?doclD = 15184 .

[37] Pandemic H1N1 2009 influenza: clinical management guidelines for adults and children. - 2009. Retrieved from www.dh.gov.uk/en/Publichealth/Flu/Swinefluguidance/DH 122629

[38] Van der Sluijs, K. F., Van der Poll, T., Lutter, R., Juffermans, N. P., \& Schultz, M. J. (2010). Bench-to-bedside review: Bacterial pneumonia with influenza-pathogenesis and clinical implications. Critical Care, 14(2), 219-227. doi: 10.1186/cc8893.

[39] Murray, R. J., Robinson, J. O., White, J. N., Hughes, F., Coombs, G. W. Pearson, J. C., et al. (2010). Community-Acquired Pneumonia Due to Pandemic A (H1N1) 2009. Influenzavirus and Methicillin Resistant Staphylococcus aureus Co-Infection. PLoS ONE, 5(1), e8705. doi: 10.1371 /journal.pone. 0008705 .

[40] Geddes, A. (2009). Influenza and bacterial pneumonia International. Journal of Antimicrobial Agents., 34(4), 293-294.

[41] Diavatopoulos, D. A., Short, K. R., Price, J. T., Wilksch, J. J., Brown, L. E., Briles, D. E., et al. (2010). Influenza A virus and Streptococcus pneumoniae facilitates disease transmission. The FASEB Journal, 24(6), 1789-98. doi: 10.1096/fj.09-146779.

[42] (2009).Centers for Disease Control and Prevention (CDC): Bacterial co infections in lung tissue specimens from fatal cases of 2009 pandemic influenza A (H1N1) United States, May-August 2009. MMWR Morb. Mortal Wkly Rep., 58, 1071-1074.

[43] Morens, D. M., Taubenberger, J. K. \& Fauci, A. S. (2008). The Predominant role of bacterial pneumonia as a cause of death in influenza pandemic: implications for pandemic influenza preparedness. J. Infect. Dis., 198(7), 962-70. doi: 10.1086/591708.

[44] Mamas, M. A., Fraser, D., \& Neyses, L. (2008). Cardiovascular manifestations associated with influenza virus infection. Int. J. Cardiol., 130(3), 304-9. doi: 10.1016/j.jijcard.2008.04.044.

[45] (2009). National Center for Immunization and Respiratory Diseases (2009) Use of influenza A (H1N1) 2009 monovalent vaccine. Recommendations of the Advisory Committee on Immunization Practices (ACIP). MMWR Recomm Rep., 58, 1-8.

[46] Van Kerkhove, M. D., Vandemaele, K. A., Shinde, V., Jaramillo-Gutierrez, G., Koukounari, A., Donnelly, C. A., et al. (2011). Risk Factors for Severe Outcomes following 2009 Influenza A (H1N1) Infection: A Global Pooled Analysis. PLoS Med., 8(7), e1001053. doi: 10.1371/ journal.pmed.1001053

[47] Simonsen, L., Clarke, M. J., Schonberger, L. B., Arden, N. H., Cox, N. J. \& Fukuda, K. (1998). Pandemic versus epidemic influenza mortality: a pattern of changing age distribution. J. Infect. Dis., 178, 53-60. doi: https://doi.org/10.1086/515616.

[48] Dawood, F. S., Jain, S., \& Finelli, L., Shaw, M. W., Lindstrom, S., Garten, R. J., et al. (2009). Emergence of a novel swine-origin influenza A (H1N1) virus in humans. N. Engl. J. Med., 360(25), 2605-15. doi: 10.1056/NEJMoa0903810.

[49] Centers for Disease and Prevention (CDC). (2009). Serum cross-reactive antibody response to a novel influenza $\mathrm{A}(\mathrm{H} 1 \mathrm{~N} 1)$ virus after vaccination with seasonal influenza vaccine. MMWR Morb. Mortal Wkly Rep., 58(19), 521-4.

[50] Domínguez-Cherit, G., Lapinsky, S. E., Macias, A. E., Pinto, R. Espinosa-Perez, L., de la Torre, A., et al. (2009). Critically ill patients with 2009 influenza A (H1N1) in Mexico. JAMA, 302(17), 1880-7. doi: 10.1001/jama.2009.1536.

[51] Salihefendic, N., Zildzic, M., \& Ahmetagic, S. (2015). Acute Respiratory Distress Syndrome (ARDS) from Endemic Influenza A/H1N1: Prehospital Management. Med Arch., 69(1), 62-3. doi: 10.5455/ medarh.2015.69.62-63

[52] Pearlman, A. N., \& Conley, D. B. (2008). Review of current guidelines related to the diagnosis and treatment of rhinosinusitis. Curr. Opin. Otolaryngology, Head Neck Surg., 16(3), 226-230. doi: 10.1097/ MOO.0b013e3282fdcc9a.
[53] Autio, T. J., Tapiainen, T., Koskenkorva, T., Närkiö, M., Lappalainen, M. Nikkari, S., et al. (2015). The role of microbes in the pathogenesis of acute rhinosinusitis in young adults. Laryngoscope, 125(1), E1-7. doi: $10.1002 /$ lary.24862.

[54] Schied, D. C., \& Hamm, R. M. (2006). Ostryj bakterial'nyj rinosinusit u vzroslyh. Obzor. Medicina neotlozhnykh sostoyanij, 5(6), 44-54. [in Russian].

[55] Aniutin, R., Kulikov, L., \& Nersesyan, M. (2005). Morfologicheskie osobennosti slizistoj obolochki klinovidnoj pazukhi u bol'nykh sfenoiditom [Morphological features of the sphenoid sinus mucosa in patients with sphenoiditis]. Rossiyskaya rinologiya, 4, 21-22. [in Russian].

[56] Andreichyn, Yu. M. (2015) Patohenetychni osoblyvosti perebihu verkhnoshchelepnykh synusytiv i remodeliuvannia synusnykh stinok (Avtoref. dis... dokt. med. nauk) [Pathogenetic features of the flow of maxillary sinusitis and remodeling of sinus walls. Dr. med. sci. diss.] Ternopil. [in Ukrainian]

[57] Lima, J. T., Paula, F. E., Proença-Modena, J. L., Demarco, R. C., Buzatto, G. P., Saturno, T. H., et al. (2015). The seasonality of respiratory viruses in patients with chronic rhinosinusitis. Am. J. Rhinol. Allergy, 29(1), 19-22. doi: 10.2500/ajra.2015.29.4129.

[58] Rowan, N. R., Lee, S., Sahu, N., Kanaan, A., Cox, S., Phillips, C. D. \& Wang, E. W. (2015). The role of viruses in the clinical presentation of chronic rhinosinusitis. Am. J. Rhinol. Allergy., 29(6), e197-200. doi: 10.2500/ajra.2015.29.4242. 